NOTE

\title{
Effect of methyl parathion on the susceptibility of shrimp Litopenaeus vannamei to experimental vibriosis
}

\author{
L. Labrie ${ }^{1,2}$, A. Roque ${ }^{2, *}$, B. Gomez-Gil ${ }^{2}$, J. F. Turnbull ${ }^{1}$ \\ ${ }^{1}$ Institute of Aquaculture, University of Stirling, Stirling FK9 4LA, UK \\ ${ }^{2}$ Centro de Investigacion en Alimentacion y Desarrollo, A.C., AP 711, CP 82000 Mazatlan, Mexico
}

\begin{abstract}
Following increasing calls for environmental safety over the past 2 decades, persistent pesticides are being replaced by more rapidly degradable products. However, even these pesticides can affect non-target species, and may be associated with slow growth and increased susceptibility to viral and bacterial infections. In this study, juvenile white shrimp Litopenaeus vannamei (also named Penaeus vannamei) were challenged by intramuscular injection with Vibrio parahaemolyticus after $4 \mathrm{~d}$ prior exposure to methyl parathion in feed pellets at $0.080 \mathrm{\mu g} \mathrm{g}^{-1}$. The bacterial injection control group consisted of shrimp fed pellets containing the methyl parathion-carrier solvent acetonitrile. Three additional control groups comprised 2 sterile saline-injection groups fed pellets containing methyl parathion or acetonitrile prior to injection, and 1 uninjected group fed normal pellets. Cumulative mortalities were recorded on the 4th and 8th days, and the presence of histological lesions was recorded on the 8th day. Cumulative mortalities were significantly higher in the group exposed to methyl parathion and bacteria on Day 8. Histological lesions, typical of vibriosis, were significantly associated with the injection of $V$. parahaemolyticus. The study provides strong experimental evidence that prior exposure to methyl parathion can increase the severity of Vibrio infections.
\end{abstract}

KEY WORDS: Shrimp $\cdot$ Vibriosis $\cdot$ Methyl parathion $\cdot$ Pesticide

\section{INTRODUCTION}

It is generally accepted that many diseases in aquatic organisms result from a combination of stressors and infectious agents. Inappropriate nutrition, treatments, handling and other environmental factors are known to be sources of stress (Sniesko 1974). Le Moullac et al. (1998) showed that severe hypoxia $\left(1 \mathrm{mg} \mathrm{O}_{2} \mathrm{ml}^{-1}\right.$ ) increased the number of mortalities in Litopenaeus stylirostris (also named Penaeus stylirostris) after Vibrio sp. injection. It has also been reported that pollutants such as heavy metals can alter normal limb regeneration and moulting in crustaceans (Weiss et al.
1992), and that copper induced avoidance reactions and changes in feeding and mating in the common shore crab Carcinus maenas (Hebel et al. 1997). Couch \& Courtney (1977) showed that low-level natural infections of Baculovirus penaei in Farfantopenaeus duorarum (also named $P$. duorarum) increased in intensity compared with controls upon exposure to 1 to $3 \mathrm{ppb}$ of polychlorinated biphenols for 10 to $25 \mathrm{~d}$.

Coastal waters are exposed to pollution from a variety of sources, including sewage effluents, industrial discharges, run-off from agricultural activity and aquacultural wastes. Agricultural fertilisers, fungicides and organophosphorous and organochlorine pesticides are 
all common pollutants of coastal water (Paez-Osuna et al. 1998). The 'new generation' of organophosphorous insecticides are extensively used in tropical agriculture. Investigations into agrochemical usage in Central America and Mexico revealed that the organophosphorous pesticides malathion, parathion, monocrotophos and clorpyrifos ranked among those most commonly used in the region (Mee et al. 1991). In addition, investigations into the distribution of some of these highly toxic compounds in the coastal areas of Central America and Mexico have revealed that they have the potential to negatively impact sensitive tropical marine ecosystems (Readman et al. 1992). Pesticide measurements in Ohuira Bay on the coast of Sinaloa, Mexico also revealed the presence of restricted and illegal pesticides (aldrin, endrin, methyl parathion, DDT and lindane) in sufficiently high concentrations to cause physiological and biochemical damage to shrimp and other animals (Galindo-Reyes et al. 1999). Thus, coastal pollution is a problem in Mexico and other areas of the world, and there is a legitimate concern about the direct and indirect effects on non-target organisms, including wild and cultured shrimp.

Vibrio species are ubiquitous in marine and brackish water ecosystems throughout the world (Lightner 1996, Vandenberghe et al. 1999), and infections with Vibrio spp. (vibriosis) are probably the most common, if not the most damaging, form of disease in cultured shrimp (Chanratchakool et al. 1998, Lavilla-Pitogo et al. 1998, Sudheesh \& Xu 2001). A combination of pollutants with infectious agents has been suggested, but not proven, as one of the potentially harmful indirect effects of pollution (Mallins \& Ostrander 1991). The main aim of this study was to evaluate the interaction between oral exposure to an organophosphate pesticide and the development of vibriosis following injection challenge with $V$. parahaemolyticus in the white shrimp Litopenaeus vannamei.

\section{MATERIALS AND METHODS}

Shrimp. White shrimp Litopenaeus vannamei juveniles were obtained from a commercial farm in the state of Sinaloa, Mexico. They arrived at the centre facilities $3 \mathrm{wk}$ before the start of the trials with a mean weight of $0.8 \mathrm{~g}(\mathrm{SD} \pm 0.2)$, and were kept in recirculating $500 \mathrm{l}$ round black PVC tanks (Rotoplas). Water was maintained at $26 \pm 2{ }^{\circ} \mathrm{C}$ and $35 \%$. The shrimp were fed once a day ad libitum on a commercial diet (Cenzone, Aquature-40\% proteins, 3.5\% lipids, $3.0 \%$ fibres, $16.0 \%$ ash, and $12.0 \%$ water).

Experimental system. A static system consisting of $25 \times 10$ l glass tanks was used for the experiments. Each tank was individually aerated and water condi- tions were maintained at a temperature of $25.4 \pm 0.3^{\circ} \mathrm{C}$, $35 \%$ salinity and $\mathrm{pH} 7.2 \pm 0.05$. From the time the shrimp were introduced to the system, a $90 \%$ water exchange was done daily by siphoning the water out and then refilling the tank with clean seawater. Aeration occurred through a glass pipette connected by an air hose to a $1 \mathrm{HP}$ air blower (Siemens).

Vibrio parahaemolyticus isolate and inoculum. V. parahaemolyticus Strain HL57 (=CAIM 170) of CIAD's collection of microorganisms important to aquaculture was originally isolated from the haemolymph of a diseased juvenile shrimp Litopenaeus vannamei sampled from a farm in the state of Sinaloa, Mexico during a vibriosis outbreak in 1994. The isolate had previously been identified as $V$. parahaemolyticus using phenotypic methods (BIOLOG GN2, Biolog). HL57 was preserved in Protect Bacterial Preservers (Technical Service Consultant) at $-70^{\circ} \mathrm{C}$ and resuscitated in $10 \mathrm{ml}$ TSB (Tryptone Soya Broth, Difco Laboratories) with $2 \%$ added sodium chloride $(\mathrm{NaCl})$ at $30^{\circ} \mathrm{C}$ for $24 \mathrm{~h}$. The cells were then washed by centrifugation (Biofuge, Primo R) 3 times at $8000 \times g$, $10^{\circ} \mathrm{C}$, for $10 \mathrm{~min}$. Bacterial density was adjusted using a spectrophotometer (610 nm; HACH DR 2010 USA) and existing standard curves for bacterial concentration against optical density at $30^{\circ} \mathrm{C}$. The resulting bacterial pellet was suspended in sterile saline solution $(2.5 \% \mathrm{NaCl})$, and brought to a final density of $10^{5}$ colony forming units (CFU) $\mathrm{ml}^{-1}$ for injection into the shrimp. The estimated density was confirmed by plate counts on TCBS (thiosulphate citrate bile salt) agar (Bioxon).

Preparation of feed. Acetonitrile (OMNISOLV AXO142-1, EM Science) was used to dissolve the methyl parathion (TECKEM, technical grade, 93\% purity) for addition to normal commercial feed pellets. Feed without methyl parathion but with acetonitrile was prepared to control for the effect of acetonitrile. Feed was stored in closed opaque glass containers at $-20^{\circ} \mathrm{C}$ until it was used.

Experimental procedure. The shrimp were acclimatised for $1 \mathrm{~d}$ then starved for $2 \mathrm{~d}$ before the beginning of the experiment. There were 5 experimental treatment groups, each with 5 replicates and 10 ind. per replicate. In the test group, shrimp were fed pellets containing methyl parathion prior to challenge with Vibrio parahaemolyticus (MPAR/V). The bacterial injection control group comprised shrimp fed with pellets containing acetonitrile (the solvent for methyl parathion) prior to challenge (V). Three additional control groups comprised 2 sterile saline injection groups fed pellets containing methyl parathion (MPAR) or acetonitrile (A) and 1 group fed untreated pellets (C). Shrimp fed the pesticide received 1 pellet containing $0.08 \mu \mathrm{g}$ methyl parathion $\mathrm{g}^{-1}$ in the morning and 1 
untreated pellet in the evening for $4 \mathrm{~d}$. The individual pellets weighed $6.7 \pm 1.0 \mathrm{mg}$.

Faeces and uneaten pellets were removed by exchanging the water in the tanks $30 \mathrm{~min}$ after feeding. From the 5th day onward, all shrimp were fed uncontaminated food. On the 5 th day, 4 of the treatment groups were injected. In groups MPAR/V and V each shrimp was injected with $20 \mu \mathrm{l}$ HL57 suspension $\left(3.39 \times 10^{5} \mathrm{CFU} \mathrm{ml}^{-1}\right)$, while in treatments MPAR and A, they were injected with $20 \mu$ sterile saline. Mortalities were recorded daily and surviving shrimp were sampled for histology on Day 8 by fixation in Davidson's fixative, and processed according to Bell \& Lightner (1988). Two $5 \mu \mathrm{m}$ tissue sections from each shrimp were stained with haematoxylin and eosin (H\&E).

Analysis. Due to non-normal distribution of data, the associations between treatments and cumulative mortalities were examined with the non-parametric Kruskal-Wallis 1-way ANOVA on ranks with Dunn's post-hoc comparison (SigmaStat for Windows $3.0^{\odot}$, 1992-2003, SPSS). The cumulative mortalities over the first $4 \mathrm{~d}$ of the experiment (shrimp in the MPAR and the MPAR/V treatments receiving methyl parathion) and the cumulative mortalities for Days 5 and 6 (after injection) were compared among treatments in separate analyses.

In order to allow statistical analysis of the histological findings, the interpretation of the slides had to be converted to a numeric form. Two slides were prepared per shrimp and the presence or absence of a variety of lesions was recorded as single dichotomous variables, i.e. 1 if the lesion was present in either slide or 0 if it was not observed. In some cases, the organ was not present in either of the slides and in these cases the shrimp were removed from the analysis.

The presence or absence of the following lesions was recorded: in the hepatopancreas, haemocytic inflammation, haemocytic nodules and tubular atrophy; in the muscle, necrosis, haemocytic inflammation and hyaline necrosis; and in the lymphoid organ, haemocytic nodules.

In order to quantify the association of each treatment with each lesion, the prevalence of a lesion within the treated group (the number of shrimp with and without lesions from all the replicates of the treatment) was compared with the prevalence in the rest of the sampled shrimp. The analysis used to evaluate the association was a relative risk analysis (or relative risk in exposed animals). This compared the ratio of the prevalence in the shrimp exposed to a treatment with the prevalence in the shrimp not exposed to the treatment. This analysis was conducted with Epi-Info 2000 software (Centers for Disease Control and Prevention [CDC]) that produced a point estimate of the relative risk (RR), $95 \%$ confidence intervals (CI) and an estimate of statistical significance (p). A relative risk greater than 1, with confidence intervals that did not pass through 1, indicated a risk factor (Smith 1995). That is, a relative risk of 2 would suggest that the lesion was twice as likely to be observed in the shrimp from that treatment compared with the other shrimp. The risk factor was taken to be statistically significant if $\mathrm{p}$ is $<0.05$.

\section{RESULTS}

From the first day of feeding, some shrimp fed with the pesticide showed whitening of the abdominal muscle, erratic swimming and swimming in circles.

\section{Mortality}

Daily mortalities are summarised in Table 1. During the first $4 \mathrm{~d}$ of the experiment prior to injection challenge, mortalities occurred only in the shrimp groups

Table 1. Daily mortalities of Litopenaeus vannamei (mean $\pm \mathrm{SD}$ ) for the 5 treatments from the start of experiment feeding pellets containing methyl parathion. The total number of dead shrimp from the 5 replicate tanks is shown in parentheses above daily mortalities. MPAR/V: methyl parathion and Vibrio parahaemolyticus; MPAR: methyl parathion; V: V. parahaemolyticus; A: acetonitrile control; C: normal pellet control

\begin{tabular}{|c|c|c|c|c|c|c|c|}
\hline Treatment & Day 1 & Day 2 & Day 3 & Day 4 & $\begin{array}{c}\text { Day } 5 \\
\text { (injection) }\end{array}$ & Day 6 & $\begin{array}{c}\text { Cumulative } \\
\text { mortality }\end{array}$ \\
\hline MPAR/V & $\begin{array}{c}(1) \\
0.02 \pm 0.04\end{array}$ & 0 & $\begin{array}{c}(1) \\
0.02 \pm 0.04\end{array}$ & 0 & $\begin{array}{c}(16) \\
0.32 \pm 0.24\end{array}$ & $\begin{array}{c}(2) \\
0.04 \pm 0.05\end{array}$ & $20(40 \%)$ \\
\hline MPAR & $\begin{array}{c}(1) \\
0.02 \pm 0.04\end{array}$ & $\begin{array}{c}(1) \\
0.02 \pm 0.04\end{array}$ & $\begin{array}{c}(1) \\
0.02 \pm 0.04\end{array}$ & $\begin{array}{c}(1) \\
0.02 \pm 0.04\end{array}$ & 0 & 0 & $4(8 \%)$ \\
\hline V & 0 & 0 & 0 & 0 & $\begin{array}{c}(5) \\
0.1 \pm 0.07\end{array}$ & $\begin{array}{c}(1) \\
0.02 \pm 0.04\end{array}$ & $6(15 \%)$ \\
\hline $\mathrm{A}$ and $\mathrm{C}$ & 0 & 0 & 0 & 0 & 0 & 0 & 0 \\
\hline
\end{tabular}


fed pellets containing methyl parathion. No mortality occurred in any of the other groups. Mortalities occurred 1 to $2 \mathrm{~h}$ after feeding, and did not exceed 1 ind. $\mathrm{d}^{-1}$ in any of the 5 replicates.

After injection challenge on Day 5, mortalities occurred only in the groups injected with Vibrio parahaemolyticus. There was no mortality in any of the other groups. Mortalities did not begin until $8 \mathrm{~h}$ postinjection, were highest on the day of injection, and continued on the following day. For the remaining $2 \mathrm{~d}$ of the test, there was no mortality in any of the groups. On the day of bacterial injection (Day 5), 5 shrimp died in the group injected with $V$. parahaemolyticus and fed acetonitrile, while 16 died in the group fed methyl parathion. There was no significant association between treatment and cumulative mortalities on Day $4(\mathrm{H}=6.878, \mathrm{df}=4, \mathrm{p}=0.142)$. The cumulative mortalities for Days 5 and 6 in the MPAR/V treatment were significantly higher than the other treatments $(\mathrm{H}=20.603, \mathrm{df}=4, \mathrm{p}<0.001)$.

\section{Histopathological analysis}

The results of the analyses are presented in Table 2 . There was a significant association between injection of Vibrio parahaemolyticus and haemocytic nodule formation in the hepatopancreas and lymphoid organ (i.e. in the MPAR/V and V groups). There were also significant associations between $V$. parahaemolyticus injec- tion and hyaline muscle necrosis and haemocytic inflammation in muscle (V group only). Tubular atrophy of the hepatopancreas was frequently associated with a lack, or low numbers, of vacuoles in R-cells; however, this proved difficult to quantify.

\section{DISCUSSION}

The most common route for experimental exposure to pesticides for aquatic animals is through water (Vogt 1987, Day \& Scott 1990, Srinivasulu et al. 1990, Srinivasulu \& Ramana-Rao 1991, Betancourt-Lozano 1999). At the time of writing there was only one study that explicitly exposed aquatic animals through the oral route to organophosphate pesticides. We considered oral administration of methyl parathion as the most appropriate exposure because Litopenaeus vannamei predominantly feeds off the benthos, and because methyl parathion is relatively insoluble in water (Badawy \& El-Dib 1984, Hertel 1993), apparently binding to organic matter. The dosages applied $(0.08 \mu \mathrm{g}$ methyl parathion $\mathrm{g}^{-1} \mathrm{~d}^{-1}$ ) were also realistic since they were consistent with those found by Galindo-Reyes et al. (1999) in the sediments from a coastal lagoon off the Gulf of California, where concentrations of methyl parathion in sediments were as high as $98.68 \mathrm{ng} \mathrm{g}^{-1}$, while those in the water did not exceed $4.04 \mathrm{ng} \mathrm{ml}^{-1}$.

The whitening of muscle and abnormal swimming behaviour we observed were only associated with

Table 2. Litopenaeus vannamei. Prevalance of lesions: results of relative risk analysis to detect associations between treatments and histopathological lesions. Results in bold indicate associations (CIs that do not pass through 1). One of the associations was not statistically significant ( $\mathrm{p}$ 0.05). RR: relative risk; CI: $95 \%$ confidence interval; ND: not detected; MPAR/V: methyl parathion and Vibrio parahaemolyticus; MPAR: methyl parathion; V: V. parahaemolyticus; A: acetonitrile; C: control. ${ }^{*}$ Treatment was associated with pathology but the relationship was not statistically significant

\begin{tabular}{|c|c|c|c|c|c|c|c|}
\hline & $\begin{array}{c}\text { Haemocytic } \\
\text { inflammation } \\
\text { hepatopancreas }\end{array}$ & $\begin{array}{c}\text { Tubular } \\
\text { atrophy } \\
\text { hepatopancreas }\end{array}$ & $\begin{array}{c}\text { Haemocytic } \\
\text { nodules } \\
\text { hepatopancreas }\end{array}$ & $\begin{array}{l}\text { Muscle } \\
\text { necrosis }\end{array}$ & $\begin{array}{c}\text { Haemocytic } \\
\text { inflammation } \\
\text { muscle }\end{array}$ & $\begin{array}{l}\text { Hyaline } \\
\text { necrosis } \\
\text { muscle }\end{array}$ & $\begin{array}{c}\text { Haemocytic } \\
\text { nodules } \\
\text { lymphoid organ }\end{array}$ \\
\hline \multicolumn{8}{|c|}{ MPAR/V } \\
\hline $\mathrm{RR}$ & 1.40 & 0.87 & 3.71 & 1.14 & 1.00 & 2.02 & 2.02 \\
\hline $\mathrm{CI}$ & $0.80-2.46$ & $0.64-1.19$ & $1.63-8.46$ & $0.86-1.52$ & $0.78-1.27$ & $1.10-3.69$ & $1.50-2.72$ \\
\hline $\mathrm{p}$ & 0.37 & 0.49 & 0.0044 & 0.53 & 0.81 & $0.057^{*}$ & 0.00023 \\
\hline \multicolumn{8}{|c|}{ MPAR } \\
\hline RR & 1.44 & 1.03 & & 0.92 & 0.82 & 0.15 & 0.65 \\
\hline CI & $0.87-2.38$ & $0.824-1.289$ & ND & $0.69-1.22$ & $0.35-1.87$ & $0.039-0.63$ & $0.41-1.04$ \\
\hline $\mathrm{p}$ & 0.23 & 0.96 & & 0.709 & 0.79 & 1.000 & 0.081 \\
\hline \multicolumn{8}{|l|}{ V } \\
\hline $\mathrm{RR}$ & 0.82 & 1.09 & 3.4 & 1.14 & 1.26 & 4.74 & 1.8 \\
\hline $\mathrm{CI}$ & $0.45-1.49$ & $0.87-1.36$ & $1.45-7.94$ & $0.88-1.472$ & $1.07-1.49$ & $2.59-8.68$ & $1.27-2.44$ \\
\hline $\mathrm{p}$ & 0.65 & 0.59 & 0.0082 & 0.43 & 0.0156 & 0.0000014 & 0.0033 \\
\hline \multicolumn{8}{|c|}{$A$ and $C$} \\
\hline RR & 0.55 & 0.97 & & 0.74 & 0.813 & & 0.28 \\
\hline $\mathrm{CI}$ & $0.266-1.12$ & $0.76-1.24$ & ND & $0.54-0.98$ & $0.63-1.01$ & ND & $0.13-0.59$ \\
\hline $\mathrm{p}$ & 0.115 & 1.0000 & & 0.85 & 0.11 & & 1.0000 \\
\hline
\end{tabular}


exposure to methlyparathion. This could have resulted from an accumulation of lactic acid through inhibition of aerobic metabolism (Reddy \& Rao 1986, 1988, Betancourt-Lozano 1999). It might also have resulted from organophosphorous inhibition of acethylcholinesterase activity (AChE) (Srinivasulu et al. 1990, Hertel 1993, Lundebye et al. 1997). The normal function of AchE is to remove the neurotransmitter acetylcholine, liberated at the cholinergic nerve endings in response to nervous stimuli (Peakall 1992, Hertel 1993). The inhibition of AchE causes an accumulation of acetylcholine at the nerve synapses and disruption of the nerve function, leading to irregular muscle contraction and other disturbances.

Tubular atrophy of the hepatopancreas and low levels of vacuolation in the R-cells were observed in all treatments, and this is indicative of poor nutritional status. The R-cells absorb soluble nutrients from the lumen of the gut and store lipid and glycogen in vacuoles (Al-Mohanna \& Nott 1987, 1989), so the absence or depletion of vacuoles indicates poor nutrition. In our trials, only 2 pellets of $0.008( \pm 0.002) \mathrm{g}$ were provided each day, and this represented only $2.2 \%$ of the body weight. By contrast, the normal feeding rate for juvenile shrimp varies between 6 and $10 \% \mathrm{~d}^{-1}$. This could explain the tubular atrophy, even in the absence of bacterial challenge.

A low number of mortalities occurred from exposure to methyl parathion alone during the $4 \mathrm{~d}$ period, prior to injection of Vibrio parahaemolyticus. After injection, mortalities were significantly higher in the group fed methyl parathion than in the group without. Prior exposure to methyl parathion increased mortality upon bacterial challenge. Histological analysis of the dead shrimp was not possible since shrimp that have been dead for even a short time are of very little value for detailed histopathological or bacteriological analyses (Mohan et al. 2002). However, survivors from the challenge provided some useful information.

In the surviving shrimp, no histopathological changes were significantly associated with oral exposure to methyl parathion. However, other studies have demonstrated histopathological changes in association with environmental pollution. Vogt (1987) described disorganisation of the hepatopancreas, detachment of cells from the basal laminae, a lack of lipid reserves, and many autolysed cells in Penaeus monodon after exposure to dimethoate. Rao \& Doughtie (1984) exposed grass shrimp Metapenaeus monoceros to toxicants, including dithiocarbamates, and reported midgut epithelial hypertrophy, cytoplasmic vacuolisation and reduction of basal tubular endoplasmatic reticulum, as well as abnormal mitosis. We observed neither mid-gut hypertrophy nor cytoplasmic vacuolation, despite the presence of mortalities in the methyl parathion-exposed groups. It is possible that lesions did occur during the $4 \mathrm{~d}$ of methyl parathion exposure, but that they were sufficiently mild to be resolved by the time of assay on Day 8. It is also possible that the duration of exposure was insufficient to produce histopathological changes and, as the analysis would suggest, the mortalities prior to injection were random events not associated with exposure to methyl parathion.

The results presented here demonstrate that pesticides can combine with infectious agents to increase the risk of disease in non-target species. The model system developed and used here reproduced mortalities and pathology associated with vibriosis.

Acknowledgements. Thanks to the Anchoveta for providing the experimental animals, and to C. Bolán-Mejìa, S. AbadRosales and C. Orantes for technical help with the analysis. This study was funded by CONACYT grant no. 34952-B and British Council grant no. mxc991/91, both awarded to A.R.

\section{LITERATURE CITED}

Al-Mohanna SY, Nott JA (1987) R-cells and the digestive cycle in P. semisulcatus. Mar Biol 95:129-137

Al-Mohanna SY, Nott JA (1989) Functional cytology of the hepatopancreas of $P$. semisulcatus during the moult cycle. Mar Biol 101:535-544

Badawy MI, El-Dib MA (1984) Persistence and fate of methyl parathion in seawater. B. Environ Contam Toxicol 33: $40-49$

Bell TA, Lightner DV (1988) A handbook of normal penaeid shrimp histology. World Aquaculture Society, Baton Rouge, LA

Betancourt-Lozano M (1999) Interactive toxicity of a triazolderivate fungicide and an organophosphate pesticide in the marine shrimp Litopenaeus vannamei. PhD thesis, University of Stirling

Chanratchakool P, Turnbull JF, Funge-Smith SJ, MacRae IH, Limsuwan C (1998) Health management in shrimp ponds, 3rd edn. Aquatic Animal Health Institute, Bangkok

Couch JA, Courtney L (1977) Interaction of chemical pollutants and virus in a crustacean: a novel bioassay system. Ann NY Acad Sci 298:497-504

Day DE, Scott IM (1990) Use of acetylcholinesterase activity to detect sublethal toxicity in stream invertebrates exposed to low concentrations of organophosphate insecticides. Aquat Toxicol 18:101-113

Galindo-Reyes JG, Fossati VU, Villagrana-Lizarraga C, Dolci F (1999) Pesticides in water, sediments, and shrimp from a coastal lagoon off the Gulf of California. Mar Pollut Bull 38:837-841

Hebel DK, Jones MB, Depledge MH (1997) Responses of Crustaceans to contaminant exposure: a holistic approach. Estuar Coast Shelf Sci 44:177-184

Hertel RF (ed) (1993) Methyl parathion. Environmental Health Criteria 145. World Health Organisation, Geneva

Lavilla-Pitogo CR, Leaono EM, Paner MG (1998) Mortalities of pond-cultured juvenile shrimp, Penaeus monodon, associated with the dominance of luminescent vibrios in the rearing environment. Aquaculture 164:337-349

Le Moullac G, Soyes C, Saulnier A, Avarre JC, Levy P (1998) Effect of hypoxic stress on the immune response and the 
resistance to vibriosis of the shrimp Penaeus stylirostris. Fish Shellfish Immunol 8:621-629

Lightner DV (1996) A handbook of shrimp pathology and diagnostic procedures for disease of cultured penaeid shrimp. World Aquaculture Society, Baton Rouge, LA

Lundebye AK, Curtis TM, Braven J, Deplege MH (1997) Effects of the organophosphorous pesticide, dimethoate, on cardiac and acetylcholinesterase (AChE) activity in the shore crab Carcinus maenas. Aquat Toxicol 40:23-36

Mallins DC, Ostrander GK (1991) Perspectives in aquatic toxicology. Annu Rev Phamacol 31:371-399

Mee LD, Readman JW, Gonzalez-Farias F (1991) Fate of agrochemicals in tropical coastal lagoon ecosystems. In: Kessler C (ed) Consolidated report of activities 1986-1990. EEC-Mexico. EUR 13970, Directorate General for Science. Research and Development Comission of European Communities, Brussels, p 113-117

Mohan CV, Corsin F, Thakur PC, Padiyar PA, Madhusudhan M, Turnbull JF, Hao NV, Morgan KL (2002) Usefulness of dead shrimp specimens in studying the epidemiology of the white spot syndorme virus (WSSV) and chronic bacterial infection. Dis Aquat Org 50:1-8

Paez-Osuna F, Guerrero-Galvan SR, Ruiz-Fernandez AC (1998) The environmental impact of shrimp aquaculture and the coastal pollution in Mexico. Mar Pollut Bull 36: 65-75

Peakall D (1992) Animal biomarkers as pollution indicators. Ecotoxicology Series, Vol. 1. Chapman \& Hall, New York

Rao KR, Doughtie DG (1984) Histopathological changes in grass shrimp exposed to chromium, pentachlorophenol and dithiocarbamates. Mar Environ Res 14:371-395

Readman JW, Liong Wee Kwong L, Mee LD, Barcotti J, Nilve G, Rodriguez-Solano JA, Gonzalez-Farias F (1992) Persistent organophosphorus pesticides in the tropical marine environments. Mar Pollut Bull 24:398-402

Editorial responsibility: Timothy Flegel,

Bangkok, Thailand
Reddy MS, Rao KVR (1986) Acute toxicity of insecticides to penaeid prawns. Environ Ecol 4:221-223

Reddy MS, Rao KVR (1988) In vivo recovery of acetylcholine esterase activity from phosphamidon and methyl parathion induced inhibition in the nervous tissue of penaeid prawn (Metapenaeus monoceros). B Environ Contam Toxicol 40:752-758

Smith RD (1995) Risk assessment and prevention. In: Smith RD (ed) Veterinary clinical epidemiology. A problem orientated approach, 2nd edn. CRC Press, Boca Raton, FL

Sniesko SF (1974) The effect of environmental stress on the outbreaks of infectious disease of fishes. J Fish Biol 6: 197-208

Srinivasulu M, Ramana-Rao KV (1991) Methyl parathion induced alterations in the tissue carbohydrate catabolism of the marine prawn, Metapenaeus monoceros. B Environ Contam Toxicol 47:925-932

Srinivasulu M, Reddy MS, Jayaprada P, Rao KVR (1990) Impact of methyl parathion on cholinergic and non-cholinergic enzyme systems of Penaeid prawn, Metapenaeus monoceros. Biochem Int 22:769-779

Sudheesh PS, Xu HS (2001) Pathogenicity of Vibrio paraheamolyticus in tiger prawn Penaeus monodon Fabricius: possible role of extracellular products. Aquaculture 196: $37-46$

Vandenberghe J, Verdonck L, Robles-Arozarena R, Rivera G and 6 others (1999) Vibrios associated with Litopenaeus vannamei larvae, postlarvae, broodstock, and hatchery probionts. Appl Environ Microbiol 65:2592-2597

Vogt G (1987) Monitoring of environmental pollutants such as pesticides in prawn aquaculture by histological diagnosis. Aquaculture 67:157-164

Weiss J, Cristini A, Rango-Rao K (1992) Effects of pollutants on moulting and generation in Crustacea. Am Zool 32: 495-500

Submitted: October 25, 2002; Accepted: August 19, 2003 Proofs received from author(s): November 26, 2003 